\title{
Candrakīrti on Deflated Episodic Memory: Response to Endel Tulving's Challenge
}

\section{Sonam Thakchoe}

To cite this article: Sonam Thakchoe (2017) Candrakīrti on Deflated Episodic Memory: Response to Endel Tulving's Challenge, Australasian Philosophical Review, 1:4, 432-438, DOI: 10.1080/24740500.2017.1411150

To link to this article: https://doi.org/10.1080/24740500.2017.1411150

曲 Published online: 06 Mar 2018.

Submit your article to this journal $\pi$

Џll Article views: 2

Q View related articles ๘

View Crossmark data $[\pi$ 


\title{
Candrakīrti on Deflated Episodic Memory: Response to Endel Tulving's Challenge
}

\author{
Sonam Thakchoe \\ University of Tasmania
}

\begin{abstract}
In my response to Ganeri's [2018] paper, I take Buddhagosha's deflationary account of episodic memory one step further through the analysis of the Madhyamaka philosopher Candrakīrti (ca. 570-640) who, like Buddhagosha, explicitly defends episodic memory as a recollection of the objects experienced in the past, rather than subjective experience. However, unlike Buddhagosha, Candrakirti deflates episodic memory by showing the incoherence of the Sautrāntika-Yogācāra's thesis that episodic memory requires the admission of reflexive awareness. Also unlike Buddhagosha, Candrakīti shows the incoherence of the Mimāmāanka-Naiyāyika's selfimplication requirement thesis, therefore directly countering Tulving's challenge to the Buddhist philosophers, by arguing that episodic memory is capable of mental time travel without any reference to the operation of enduring self. I will thus suggest that Candrakirti may have even greater success in deflating the self-implication requirement of episodic memory.
\end{abstract}

\section{ARTICLE HISTORY Received 25 September 2017; Revised 5 December 2017}

KEYWORDS episodic memory; deflated episodic memory; inflated episodic memory; reflexive cognition; proprietary attention; Candrakīrti; Sautrāntika-Yogācāra; Mimāỉsāka-Naiyāyika

\section{Endel Tulving's Challenge}

According to Endel Tulving, mental time travel is the reliving or re-experiencing, or a relocating of oneself in subjective time by mentally travelling back into the past or into the future. Since such time travelling necessarily implies a traveller without which there can be no mental time travel, and that the traveller, Tulving claims, is none other than the self; episodic memory is distinctive in satisfying the self-implication requirement since it operates with the self [Tulving 2005: 14]. Thus, Tulving's challenge to the Buddhist philosophers, given their denial of the self, is clear: they cannot pull off advancing a coherent account of episodic memory, and without that, the notion of mental time travel also becomes incoherent for the Buddhist philosophers.

\section{Ganeri's Call to Respond}

Jonardon Ganeri [2018], in his target essay, 'Mental Time Travel and Attention', has rightly drawn our attention to the topic of episodic memory and has made a timely call 
upon Buddhist philosophers to give it the due consideration it deserves. In his paper, Ganeri considers three Buddhist accounts of episodic memory: Buddhaghosa [c. $400 \mathrm{CE}$ ], Vasubandhu [c. 316-396], and Dignāga [c. 480-540 CE]. Of the three accounts, Ganeri concludes that Buddhagosha's theory of memory may be the most promising Buddhist alternative and that it could potentially counter Tulving's challenge. According to Ganeri, Buddhagosha's chief argument is that episodic memory consists of a proprietary kind of attention to objects from past perceptual encounters without making any explicit reference to the subjective experience. Buddhagosha's account, therefore, has greater success in deflating the self-implication requirement in contrast to Vasubandhu's and Dignāga's account which requires making an explicit reference to the subjectivity via reflexivity.

But there is at least one other Buddhist philosopher for whom this debate is familiar philosophical terrain and whose analysis may better support the argument for the efficacy of deflated memory. In my commentary on Ganeri's paper, I aim to bring to light the analysis of the Madhyamaka philosopher Candrakirti [ca. 570-640] to take Buddhagosha's deflationary account of episodic memory one step further. Like Buddhagosha, Candrakïrti explicitly defends a deflationary account of memory as consisting of cognitive ability to recollect in the future the past objects or actions in virtue of proprietary attention directed towards them without making any explicit reference to a reflexive recollection of the past subjective experience.

But first let us briefly turn to Candrakìrti's critiques of the inflationary account of memory: (1) the Sautrāntika-Yogācāra reflexive awareness-implicating memory thesis and (2) the Mimāminsāka-Naiyāyika's self-implicating memory thesis. Both these critiques have a direct bearing on countering Tulving's challenge for Buddhist philosophy.

\section{Critique of Reflexivity Implicating Memory Theory}

First, the Sautrāntika-Yogācāra claims that memory includes both the recollection of the object and the recollection of the subject seeing the object. Without reflexive cognition the recollection of the subjective experience is not possible. Therefore, reflexive cognition must exist [Madhyamakāvatārabhāşya MABh VI.72, dBu ma 'a 272a].

Candrakirti, however, regards the reflexivity implicating account of memory to be incoherent, stating:

It is not proven that [a cognition] is aware of itself. Nor can this be proven by using the subsequent memory [of a previous cognition as evidence], for, in this case, the thesis intended to substantiate your claim itself entails an unproven premise, and therefore it cannot be admitted as valid proof] [Madhyamakāvatāra MA VI.73, trans. Huntington 1989: 166, modified].

For Candrakirti, the reflexivity thesis is incoherent. The first chapter of Mūlamadhyamakakārikā has shown that it is not possible to prove the existence of reflexive cognition because the production of intrinsic memory, which the SautrāntikaYogācāra appropriates as the proof, has been decisively shown to be impossible [MA VI.8ab]. The argument goes like this:

1. We have reflexive cognition

2. Because we have an intrinsic episodic memory.

The argument fails to prove the existence of episodic memory because the premise itself needs to be proven [MABh VI.73, dBu ma 'a 272b-273a]. It is like this circular argument: 
1. Sound is impermanent

2. Because it is visually perceptible.

In this argument, the premise is unproven and thus it cannot be used as an evidence for the conclusion. Likewise, the Sautrāntika-Yogācāra argument's premise-intrinsic episodic memory-remains unproven like its unproven conclusion-reflexive awareness. It is therefore incoherent to appropriate memory to prove the existence of reflexive cognition [MABh VI.73, dBu ma 'a 273a].

Even if we grant that memory is conventionally real, still it cannot prove the existence of reflexive cognition because the reflexivity of cognition is not established in any example that does not already presuppose what the Sautrāntika-Yogācāra is trying to show: a sword does not cut itself; a finger-tip does not touch itself, etc. It is unreasonable that cognition should reflexively apprehend itself because there is an implicit inconsistency in the notion of introspective activity (svātmanivrtti) [MABh VI.72-3, dBu ma 'a 271-3a].

\section{Critique of the Self-Implicating Memory Theory}

Second, Âryadeva formulates the self-implicating memory argument as follows:

1. Self is eternal

2. Because a recollection of other lives is possible [Catuhśataka, CŚV X.6].

Candrakìrti offers the reconstruction of Āryadeva's formulation of his opponent's selfimplicating memory argument this way:

The self is eternal because there is a memory of previous life. A memory of previous birth is not feasible for causally conditioned entities of other lives whose nature is to disintegrate no sooner than where they arise, and whatever arises subsequently invariably differ from its antecedent. Therefore, it is not possible to have the recollection of one's past lives, such as remembering: "I had this type of life" or "I had that type of life in the past." But because the self is eternal it can travel across lives making the recollection of one's past lives possible [Catuhśatakatìikā CŚT X.6, dBu ma Ya 161b-1621a].

This account of self-implicating memory, as Ganeri [2018] has shown in his paper, closely resembles Tulving's notion of episodic memory, both of which insists on the entailment of enduring self. Tulving [1985: 1] claims, autonoetic consciousness 'mediates an individual's awareness of his or her existence and identity in subjective time extending from the personal past through the present to the personal future'.

Against the self-implicating memory thesis, Āryadeva advances this reductio ad absurdum argument:

If your self is eternal

Because of remembering life,

Why is your body not eternal

In virtue of the sight of scar formed in the previous life? [CŚV X.7].

We can unpack this reductio into two separate arguments:

1. There is, in this life, a memory of the past life.

2. Therefore, the self must be eternal. 
We shall call this the self-implicating memory argument.

1. There is a sight of the birthmark in this life of the wound caused in the past life.

2. Therefore, the body must be eternal.

We shall call this the body-implicating sight argument.

The Mādhyamika contention is that the Naiyāyika-Mīmāmsāka and, by implication, Tulving should either accept both the arguments or reject both the arguments [CŚT X.7, dBu ma Ya 162a].

If it makes sense that the self, which while entirely causally produced, is reified to be eternal entity just because there is a memory of the past lives, then the body too should be reified as eternal. But if you assert the body is not eternal [mutatis mutandis], there is no such thing as eternal self [CŚT X.7, dBu ma Ya 162a].

According to Candrakirti, Tulving does not have any sound justification to prefer the self-implicating memory thesis over the body-implicating sight thesis, without committing a self-contradiction. If a memory of the past subjective experience is a proof of the eternity of the self, mutatis mutandis, in light of this logic Tulving will need to accept the sight of a birthmark in this life of the past wound as a valid proof of the eternity of the body. If, however, Tulving wants to claim that a sight of birthmark in this life does not prove the eternity of the body, then mutatis mutandis, he will need to accept that memory as well does not prove the eternity of the self.

Therefore, Candrakirti concludes:

the arguments discussed above and will discuss below demonstrate [the self-implicating memory theory] is fallacious. Just as the memory of births arises, it is possible to produce the sight of a birthmark in this life resembling the injury in the past. Therefore, it does not follow from the fact of a memory of the births that there is an eternal self. Otherwise, it would follow the absurd conclusion that the body is eternal [CŚT X.7, dBu ma Ya 162ab].

\section{Mādhyamika Deflationism and Episodic Memory}

Let us now turn to Candrakirti's account of memory. For Candrakirti the continuum of a person is a wholly conditioned phenomenon, exclusively existing as impermanent, determined by the particularities of their causes and conditions and upon which we designate 'I', 'self, as an appropriating agent. It is thus reasonable to say: 'I remember my life' without making any explicit reflexive reference to an enduring self [CŚT X.7, dBu ma Ya 162a].

On the other hand, [according to us] memory is no different from [a cognition involved in] the experience of the object, and therefore one's own memory occurs in the form "I saw [a particular object]." That is the position taken for granted in everyday experience [MA VI.75, trans. Huntington 1989: 166]

All cognitive subjects arise dependently from their respective cognitive objects. Memory cognition follows the same convention: it arises from the object it remembers. When we remember a blue object, we remember it by means of memory cognitionthe subject-that arises from the recollecting of the object, since the cognitive subject is an integral part of the object memory-making process, there is, therefore, no need for a separate memory of the subject. Hence memory of the subject arises together with a memory of the object. Nonetheless, memory does not fully differentiate the perceptive 
perspective taken by the experiencing cognitive subject, so one just thinks, 'I saw it.' That again, says Candrakirit, is the procedure of the world, satisfying social convention [MABh VI.74, dBu ma 'a 273b].

In the Pañcaskandhaprakarana (PSP), Candrakirti says memory's ability to recall the events we have done, or were in the process of doing, arises from proprietary attention directed towards the object that we currently apprehend and that we recollect in the future. When the application of proprietary attention to the object is not present; memory cognition fails to remember [PSP dBu ma Ya 262a].

But there is no one particular past object that we could make to act as a reservoir of memory. In other words, the object we remember is not exactly the same object we saw earlier. There is no persistent object that could present itself twice: to a present cognition and a future memory cognition [CŚT XI.9, dBu ma Ya 182b]. Elucidating the type of object is at issue in memory, Âryadeva states:

Things that [are] seen do not reappear

Nor does that awareness arise again.

Memory is about cessation,

Its object invariably consists of what has been ceased [CŚṬ XI.10, dBu ma Ya 182b].

The objects we visually apprehend now, that same object cannot reappear in the future for another cognition. That is because both cognitive subjects and objects are transient and empty of intrinsic nature, ontologically deflated, and dependent upon the conditions from which they arise. Since they lack any intrinsic nature, subjects and objects undergo change conditioned by the causes from which they arise. Thus, a blue object of the past cannot reemerge in the same persistent mode as an object of the subsequent memory consciousness, for it is not possible for an entity to remain the same at any two different moments, given the law of universal impermanence. When the former blue object does not exactly reappear in the future to any cognition, it is not possible for any memory cognition to arise from that particular blue object which is not there anymore-therefore, it is not possible for memory cognition to arise from that same blue object we saw in the past.

The implication, then, is that the type of object to which memory cognition is directed towards or engages with is the past object that has now ceased and now no longer exists. Hence Âryadeva says, 'memory is about cessation, its object invariably consists of what has been ceased' [CŚT XI.10, dBu ma Ya 182b]. Candrakirti's commentary gets to the heart of the argument at issue:

Does this imply that there is no memory that could recall the past subjective experience? Who would claim, "there isn't"? We do not deny the existence of a dependently originated [memory]. We accept the facticity of memory as it is as Ācārya [Āryadeva] defines it: "Memory is about cessation; its object invariably consists of what has been ceased." Therefore, the perceptual object of memory is invariably a bygone object.

If past things are intrinsically real, and that there is a memory that takes up that as its object, that memory will also have to be intrinsically real. However, since past events are not intrinsically real, a memory that takes up those entities as its perceptual object also does not have intrinsic nature. It is thus evident that memory is about "cessation."

The meaning of the term "cessation" is not, however, different from "that which lacks intrinsic reality", "that which dependently originates" because "cessation" does not mean "nonexistence." It is not the case that all the past things are entirely nonexistent since they are objects of memory and that their effects are observable. But the ceased entities are not intrinsically real, for 
[intrinsic reality] would absurdly make them eternal, and they would absurdly be observable presently.

Memory arises representing the type of object from which it arises, and memory also has the same representation. Therefore, since memory is about recollecting a ceased entity, its objects must be those that are ceased. It is like recalling when awake the objects experienced in a dream [CŚṬ XI.10, dBu ma Ya 182b].

Candrakirti explains the relationship between a ceased object and memory consciousness with a dream analogy. Let us suppose that a person dreams of having sex with a beautiful woman. When he wakes up from his sleep, he still remembers the woman and his experience and becomes intensely obsessed. Even though there is a considerable lapse of time (between the dream of having an intercourse with the woman and the recalling of his experience while awake) and both the woman in the dream, and the sensory experience, having long ceased, but still the 'bygone objects' and the 'bygone experience' causally trigger passionate memories to arise in the mind of the person. In this way, the former experience of the objects through proprietary attention that went out of existence is causally productive in triggering new memories. It works just in the same way as the woman in the dream and the experience associated with it. Although both have long ceased, they still causally produce passion in the mind of the passionate. Candrakirti concisely puts the argument in this way:

Just as a naïve person may remember the objects apprehended during his dream and become attached to them even though he is awake; even so, [memory cognition] as an effect may arise out of the act [of proprietary attention towards the object] that has already ceased and that had no intrinsic nature [Candrakirti, MA VI.40 Skt. ed. Xuezhu, Li.].

All mental events-for example, proprietary attention-are constituted by a series of constantly disintegrating and arising phenomenological events, which upon their ceasing leave impregnated impressions in the mind sustaining the phenomenological continuum of the aggregates. Consequently, when all the conditions appropriately gather, despite the considerable lapse of time, previously ceased experience ripens in the form of impregnated memory dispositions producing memory as its effect.

Stating the argument concisely:

1. Because proprietary attentive action does not arise intrinsically, it does not cease intrinsically either.

2. Because it is possible for a future cognition to arise as an effect from a proprietary attention which has not intrinsically ceased, memory cognition can dependently arise from the cessation of proprietary attention.

3. The proprietary attentive action that has not intrinsically ceased thus indeed very plausibly maintains its interdependent causal connection with a memory cognition as its effect [MABh VI.39 dBu ma 'a: 260a].

\section{Conclusion}

Thus, it is clear, in comparison with Buddhaghosa, Candrakirti's arguments have greater purchase in deflating the self-implication requirement of episodic memory. As a matter of fact, the key to the efficacy of memory cognition is the causal efficacy of ontologically deflated subjects and the objects involved in the process of memory making. Proprietary attention and the object towards which it is directed both cease 
dependently, but they do not cease intrinsically. Even so, episodic memory as an effect arises dependently from them, but it is not produced intrinsically; thus completely abandoning any reference to metaphysically thick notions of the Sautrāntika-Yogācāra's reflexive awareness, Tulving's self or the Mimāmsāka-Naiyāyika's ātman to account for memory.

\section{Disclosure statement}

No potential conflict of interest was reported by the author.

\section{Funding}

This work is supported by the Australian Research Council [ARC DP1601000947]

\section{References}

Āryadeva. Treatise of Four Hundred Verses (Catuhśatakaśastrakārikā). Toh. 3846. bStan 'gyur, sDe dge edition. dBu ma Vol. Tsha 1b-18a.

Candrakirti 2015. Introduction of the Middle Way (Madhyamakāvatāra-kārikā). Skt. text ed. by Li Xuezhu. Journal of Indian Philosophy 43:1-30. Toh. 3861. bStan 'gyur, sDe dge edition. dBu ma Vol. 'a, 201b-219a.

Candrakïrti. Commentary on Four Hundred Verses (Catuhsatakațika). Toh. 3865. bStan 'gyur, sDe dge edition. dBu ma Vol. Ya, 30b-239a.

Candrakïrti. Commentary on Introduction of the Middle Way (Madhyamakāvatārabhāsya). Toh. 3862. bStan 'gyur, sDe dge edition. dBu ma Vol. 'a, 220b-348a.

Candrakirti. The Chapter on the Five Aggregates (Pañcaskandhaprakarana). Toh.3866. bStan 'gyur, sDe dge edition. dBu ma Vol. Ya, 239b-266b.

Ganeri, J. 2018. Mental Time Travel and Attention. Australasian Philosophical Review 1/4: 353-73.

Huntington, C. W. 1989. The Emptiness of Emptiness: An Introduction to Early Indian Mādhyamika. Honolulu: University of Hawaii Press.

Tulving, E. 1985. Memory and Consciousness, Canadian Psychology/Psychologie Canadienne, 26/1: 1-12.

Tulving, E. 2005. Episodic Memory and Autonoesis: Uniquely Human? In The Missing Link in Cognition: Origins of Self-reflective Consciousness, ed. Herbert S. Terrace and Janet Metcalfe, Oxford: Oxford University Press: 3-56. 